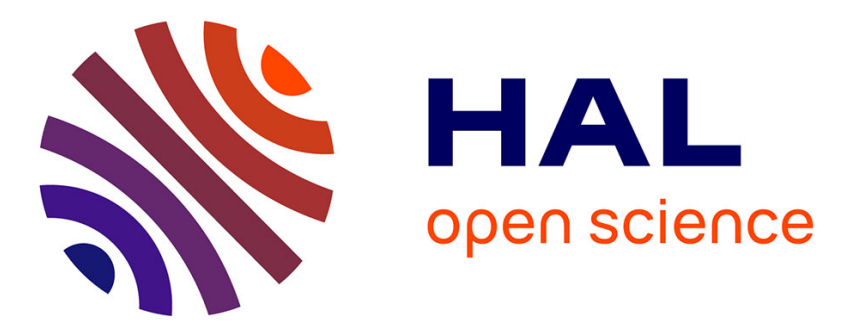

\title{
Nutritional and hormonal control of lipolysis in isolated gilthead seabream (Sparus aurata) adipocytes
}

\author{
A. Albalat, P. Gomez-Réqueni, P. Rojas, Françoise Médale, Sadasivam S. \\ Kaushik, G.J. Vianen, G. van den Thillart, J. Gutíerrez, J. Perez-Sanchez, \\ Isabelle Navarro
}

\section{To cite this version:}

A. Albalat, P. Gomez-Réqueni, P. Rojas, Françoise Médale, Sadasivam S. Kaushik, et al.. Nutritional and hormonal control of lipolysis in isolated gilthead seabream (Sparus aurata) adipocytes. AJP - Regulatory, Integrative and Comparative Physiology, 2005, 289 (1), pp.R259R265. 10.1152/ajpregu.00574.2004 . hal-02680326

\section{HAL Id: hal-02680326 \\ https: / hal.inrae.fr/hal-02680326}

Submitted on 31 May 2020

HAL is a multi-disciplinary open access archive for the deposit and dissemination of scientific research documents, whether they are published or not. The documents may come from teaching and research institutions in France or abroad, or from public or private research centers.
L'archive ouverte pluridisciplinaire HAL, est destinée au dépôt et à la diffusion de documents scientifiques de niveau recherche, publiés ou non, émanant des établissements d'enseignement et de recherche français ou étrangers, des laboratoires publics ou privés. 


\section{A. Albalat, P. Gómez-Requeni, P. Rojas, F. Médale, S. Kaushik, G. J. Vianen, G. Van den Thillart, J. Gutiérrez, J. Pérez-Sánchez and I. Navarro \\ Am J Physiol Regulatory Integrative Comp Physiol 289:259-265, 2005. First published Mar 3, 2005; doi:10.1152/ajpregu.00574.2004}

You might find this additional information useful...

This article cites 32 articles, 8 of which you can access free at:

http://ajpregu.physiology.org/cgi/content/full/289/1/R259\#BIBL

This article has been cited by 1 other HighWire hosted article:

Targets for TNF \{alpha\}-induced lipolysis in gilthead sea bream (Sparus aurata L.)

adipocytes isolated from lean and fat juvenile fish

L. Cruz-Garcia, A. Saera-Vila, I. Navarro, J. Calduch-Giner and J. Perez-Sanchez

J. Exp. Biol., July 15, 2009; 212 (14): 2254-2260.

[Abstract] [Full Text] [PDF]

Updated information and services including high-resolution figures, can be found at:

http://ajpregu.physiology.org/cgi/content/full/289/1/R259

Additional material and information about American Journal of Physiology - Regulatory, Integrative and Comparative Physiology can be found at:

http://www.the-aps.org/publications/ajpregu

This information is current as of November 10, 2010 .

The American Journal of Physiology - Regulatory, Integrative and Comparative Physiology publishes original investigations that illuminate normal or abnormal regulation and integration of physiological mechanisms at all levels of biological organization, ranging from molecules to humans, including clinical investigations. It is published 12 times a year (monthly) by the American

Physiological Society, 9650 Rockville Pike, Bethesda MD 20814-3991. Copyright @ 2005 by the American Physiological Society. ISSN: 0363-6119, ESSN: 1522-1490. Visit our website at http://www.the-aps.org/. 


\title{
Nutritional and hormonal control of lipolysis in isolated gilthead seabream
}

\section{(Sparus aurata) adipocytes}

\author{
A. Albalat, ${ }^{1}$ P. Gómez-Requeni, ${ }^{2}$ P. Rojas, ${ }^{1}$ F. Médale, ${ }^{3}$ S. Kaushik, ${ }^{3}$ G. J. Vianen, ${ }^{4}$ \\ G. Van den Thillart, ${ }^{4}$ J. Gutiérrez, ${ }^{1}$ J. Pérez-Sánchez, ${ }^{2}$ and I. Navarro ${ }^{1}$ \\ ${ }^{1}$ Departament de Fisiologia, Facultat de Biologia, Universitat de Barcelona, Barcelona, Spain; ${ }^{2}$ Instituto Acuicultura Torre \\ de la Sal, Castellón, Spain; ${ }^{3}$ Laboratoire de Nutrition des Poissons, Unitée Mixte INRA-IFREMER, Saint-Pée-sur-Nivelle, \\ France; ${ }^{4}$ Department of Integrative Zoology, Institute Biology, Leiden University, Leiden, The Netherlands
}

Submitted 23 August 2004; accepted in final form 26 February 2005

\begin{abstract}
Albalat, A., P. Gómez-Requeni, P. Rojas, F. Médale, S. Kaushik, G. J. Vianen, G. Van den Thillart, J. Gutiérrez, J. Pérez-Sánchez, and I. Navarro. Nutritional and hormonal control of lipolysis in isolated gilthead seabream (Sparus aurata) adipocytes. Am J Physiol Regul Integr Comp Physiol 289: R259-R265, 2005. First published March 3, 2005; doi:10.1152/ajpregu.00574.2004.-We examined the effects of diet composition and fasting on lipolysis of freshly isolated adipocytes from gilthead seabream (Sparus aurata). We also analyzed the effects of insulin, glucagon, and growth hormone (GH) in adipocytes isolated from fish fed with different diets. Basal lipolysis, measured as glycerol release, increased proportionally with cell concentration and time of incubation, which validates the suitability of these cell preparations for the study of hormonal regulation of this metabolic process. Gilthead seabream were fed two different diets, FM (100\% of fish meal) and PP (100\% of plant protein supplied by plant sources) for $6 \mathrm{wk}$. After this period, each diet group was divided into two groups: fed and fasted (for 11 days). Lipolysis was significantly higher in adipocytes from PP-fed fish than in adipocytes from FM-fed fish. Fasting provoked a significant increase in the lipolytic rate, about threefold in isolated adipocytes regardless of nutritional history. Hormone effects were similar in the different groups: glucagon increased the lipolytic rate, whereas insulin had almost no effect. $\mathrm{GH}$ was clearly lipolytic, although the relative increase in glycerol over control was lower in isolated adipocytes from fasted fish compared with fed fish. Together, we demonstrate for the first time that lipolysis, measured in isolated seabream adipocytes, is affected by the nutritional state of the fish. Furthermore, our data suggest that glucagon and especially GH play a major role in the control of adipocyte lipolysis.
\end{abstract}

fish; nutritional and hormonal regulation; insulin; glucagon; growth hormone; fasting

ADIPOSE TISSUE PLAYS A CENTRAL role in energy homeostasis in storing lipids in the form of triacylglycerols and in mobilizing them via breakdown into free fatty acids (FFAs) and glycerol (34). Adipose tissue is one of the most important lipid stores in several teleosts, although in some species liver or muscle also constitutes lipid storage organs (33). In salmonids, adipose tissue is distributed primarily in the abdominal cavity, associated with the mesenteric and pyloric ceca (31). In gilthead seabream, adipose tissue is also located periviscerally. It is known that fish adiposity changes seasonally and is affected by trophic status. High-fat feeds can lead to increases in visceral fat (4), resulting in reduced product yield and quality of cultured fish (7). In gilthead seabream, replacing fish meal with

Address for reprint requests and other correspondence: I. Navarro, Departament de Fisiologia, Facultat de Biologia, Universitat de Barcelona, Avda. Diagonal 645, Barcelona, Spain (e-mail: mnavarro@ub.edu). plant protein seems to alter lipid metabolism and results in smaller fat depots (10).

Endocrine control of adipose tissue mobilization and storage remains almost unexplored in fish, although insulin and glucagon are clearly involved $(12,24,28)$. Key hepatic enzymes in lipid metabolism such as hepatic lipase and acetyl-CoA carboxylase are also regulated by pancreatic hormones in vitro in isolated hepatocytes or in vivo in injected fish $(13,21)$. Several in vivo studies suggest that growth hormone $(\mathrm{GH})$ and somatolactin act together, in a complementary way, to regulate fat stores in gilthead seabream $(4,20)$. However, knowledge regarding the direct actions of hormones on fish adipose tissue is limited, and the results are contradictory. Harmon and Sheridan (12) reported that insulin and glucagon are able to regulate the level of lipolysis through triacylglycerol lipase in adipose tissue pieces of rainbow trout. Migliorini et al. (19) found that neither catecholamines nor glucagon affected the levels of lipolysis in slices of adipose tissue in the wolf fish Hoplias malabaricus. More recently, it was reported that norepinephrine and isoproterenol decreased lipolysis in adipocytes from tilapia (41) and rainbow trout (1). However, the role of possible lipolytic/antilipolytic hormones in the endocrine control of adiposity in teleosts remains to be examined in detail.

The objective of this study was first to assess how nutritional status and diet composition affect the level of lipolysis in isolated adipocytes of gilthead seabream (Sparus aurata). Second, the effects of insulin, glucagon, and GH on lipolysis were analyzed in these cells. This work is part of a more extensive study in which the effects of dietary plant protein supply in growth performance, nitrogen metabolism, and GH liver axis activity have been monitored.

\section{MATERIALS AND METHODS}

Animals and experimental conditions. Isoproteic and isolipidic diets were formulated with fish meal (FM diet) and different plant protein sources (corn gluten, wheat gluten, extruded peas, rapeseed meal, and sweet white lupin) to replace $100 \%$ of fish meal protein (PP diet). Indispensable amino acids were added to plant protein-based diets, meeting the theoretical indispensable amino acid requirement (Table 1).

Experiments were performed to standardize conditions for adipocyte incubations in adult seabream. Fish were acclimated to laboratory conditions at the Instituto de Acuicultura de Torre de la Sal, Castellón, Spain. Fish were fed daily with a commercial diet.

The costs of publication of this article were defrayed in part by the payment of page charges. The article must therefore be hereby marked "advertisement" in accordance with 18 U.S.C. Section 1734 solely to indicate this fact. 
Table 1. Ingredient and chemical composition of the two diets (FM and PP)

$\overline{\overline{\mathrm{FM}}}$

Ingredient, $\mathrm{g} / \mathrm{kg}$

Fish meal (low temperature) 704

Corn gluten meal

250

Wheat gluten

Extruded peas (Aquatex)

Rapeseed meal (Primor 00)

Lupin, sweet white

Extruded whole wheat $\quad 142$

Fish oil 124

Binder (sodium alginate) 10

Mineral premix*

Vitamin premix*

$\mathrm{CaHPO}_{4} \cdot 2 \mathrm{H}_{2} \mathrm{O}(18 \% \mathrm{P})$

Amino acid mix

10

\section{Chemical composition}

Dry matter, $\mathrm{g} / \mathrm{kg}$

Crude protein, g/kg dry matter

Crude fat, g/kg dry matter

Gross energy, MJ/kg dry matter

Sum of essential amino acids

Sum of dispensable amino acids

Essential-to-dispensable amino acid ratio

FM, fish meal diet; PP, plant protein diet. See text for further details regarding the diets. Amino acid mix contained the following: $15.9 \mathrm{~L}-\mathrm{Arg} \mathrm{HCl}$, 4.8 L-His, 32.5 L-Lys, 5.4 DL-Met, 2.9 L-Trp, 10.4 L-Thr, 8.4 L-Ile, and 11 L-Val. *According to National Research Council. Nutrient Requirements of Fish. Washington, DC: National Academy Press, 1993.

Experiments were performed in June under natural conditions of light (16:8-h light-dark cycle) and temperature $\left(22^{\circ} \mathrm{C}\right)$, with latitude $40^{\circ} 5^{\prime} \mathrm{N}, 0^{\circ} 10^{\prime} \mathrm{E}$. Water flow was $20 \mathrm{l} / \mathrm{min}$, and oxygen content of outlet water remained above $85 \%$ air saturation.
To study the effects of dietary protein sources, fish of 96-98 g initial body mass were distributed in four 500-liter tanks with groups of 40 fish/tank. Water temperature ranged from 23 to $25^{\circ} \mathrm{C}$ during the 6-wk trial (August-September 2002). Fish from two tanks were fed the FM diet, and fish from the other two tanks were fed the PP diet. Each diet was offered to apparent visual satiety in one meal per day (10:00 AM), and feed consumption was recorded daily. After this period, each dietary group was divided into two subgroups: one group was fed to apparent visual satiety (FM- and PP-fed groups) and the other group was fasted for 11 days (FM- and PP-fasted groups).

Adipocyte isolation experiments were performed in triplicate (on 3 consecutive days), and each day five or six fish from each experimental group were used. Fish were killed with a sharp blow to the head, and blood samples were taken by caudal puncture using heparinized syringes. Control fish were sampled $24 \mathrm{~h}$ after the last meal. The fish were weighed immediately, and the adipose tissue was dissected. The adipose tissue was weighed, and $10 \mathrm{~g}$ of adipose tissue from five or six animals were pooled and used for each experiment and condition. Blood samples were centrifuged, and different aliquots of plasma were kept at $-20^{\circ} \mathrm{C}$ until the day of analysis.

Experiments were conducted according to the Catalan government's Departament de Medi Ambient i Habitatge; Generalitat de Catalunya regulations concerning treatment of experimental animals (no. 2215).

Adipocyte isolation. Adipocytes were isolated as described by Vianen et al. (41), with some minor modifications. Fat tissue was cut into thin pieces and incubated for $60 \mathrm{~min}$ in polypropylene tubes with Krebs-HEPES buffer preaerated with $5 \% \mathrm{CO}_{2}$ in $\mathrm{O}_{2}(\mathrm{pH} 7.4)$ containing collagenase type II $(130 \mathrm{U} / \mathrm{ml})$ and $1 \% \mathrm{BSA}$, in a shaking water bath at $18^{\circ} \mathrm{C}$. The cell suspension was filtered through a double layer of nylon cloth and then washed three times. Finally, cells were carefully resuspended at the desired concentration in Krebs-HEPES buffer containing 2\% BSA using a Fuchs-Rosenthal counting chamber. Aliquots of $400 \mu \mathrm{l}$ of this final adipocyte suspension were incubated for $6 \mathrm{~h}$ in polypropylene tubes (4 tubes for each basal
Fig. 1. A: photomicrograph of seabream adipocytes, suspension of unfixed and unstained adipocytes $(\times 100)$. Also shown are details of a single fat cell stained with Hoechst $(B)$ and 2 adipocytes stained with May-Grünwald/giemsa $(C)$.
A

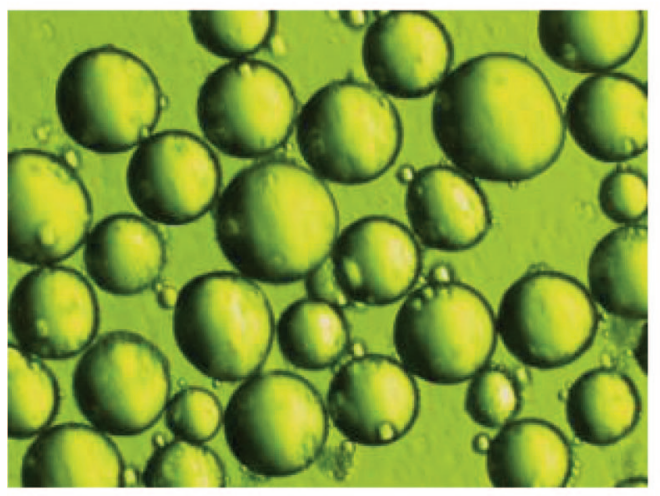

C

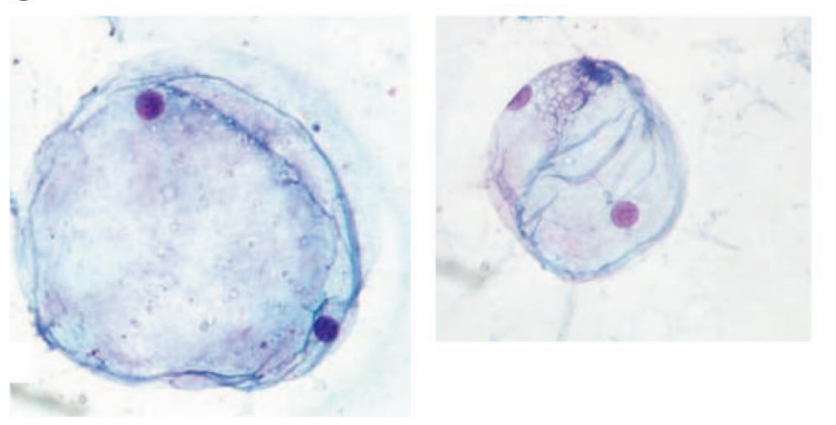

B

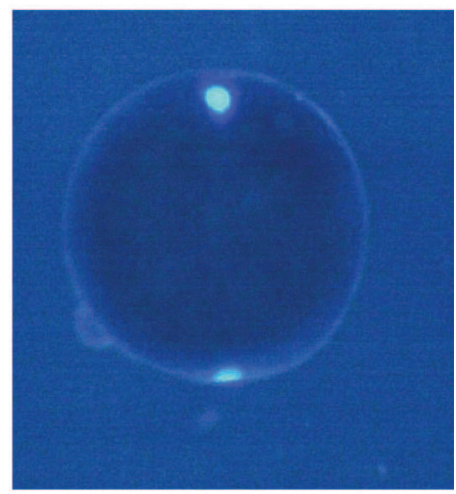


condition and 3 tubes for each concentration of hormone tested) in a shaking bath $\left(22^{\circ} \mathrm{C}\right)$ in the absence or presence of different hormones. At the end of the incubation, tubes were rapidly placed on ice; after a short centrifugation $\left(1,800 \mathrm{~g}\right.$ for $\left.2 \mathrm{~min}, 4^{\circ} \mathrm{C}\right)$, cell-free aliquots of the medium were immediately placed into perchloric acid to give a final concentration of $2 \%$. Neutralized supernatants were taken for the measurement of glycerol concentration (as an index of lipolysis) using an enzymatic method with glycerokinase and glycerol phosphate dehydrogenase as described by Tebar et al. (36). Results are the average of tetraplicates for basal conditions and triplicates for each concentration of hormone tested in three independent experiments.

Suspensions were stained with Trypan blue and examined under light microscope at different times to check the integrity and viability of the cells (Fig. 1A). To visualize the nuclei, adipocytes were stained with Hoechst $(4 \mu \mathrm{g} / \mathrm{ml})$ and with May-Grünwald/giemsa.

Biochemical analyses of plasma parameters. Plasma glucose concentration was determined by the glucose oxidase colorimetric method (GLUCOFIX; Menarini Diagnostics, Firenze, Italy) $(15,29)$, and plasma FFAs were analyzed with the use of a commercial enzymatic method (NEFA-C, Wako Test). We measured plasma insulin levels by radioimmunoassay using bonito insulin as standard and a rabbit anti-bonito insulin as antiserum (11).

Materials. Hormones used were as follows: porcine insulin (10 and $100 \mathrm{nM}$ ) from Sigma (Madrid, Spain); porcine glucagon (10 and 100 $\mathrm{nM}$ ) from Sigma; and recombinant gilthead seabream GH (0.1-10 $\mathrm{nM}$ ), produced as described elsewhere (18).

Statistical analysis. All data are presented as means \pm SE. Results were analyzed by one-way ANOVA, followed by Tukey's test when variances were homogeneous, and otherwise by the Games-Howell test (following Levene's test for the study of the homogeneity of variance). The effects of the hormones were analyzed by paired $t$-test.

\section{RESULTS}

Standardizing protocol for the study of adipocyte lipolysis. Figure $1 A$ shows a photomicrograph of isolated gilthead seabream adipocytes with a magnification of $100 \times$. Figure $1, B$ and $C$, shows single adipocytes with the double nuclei characteristic of fish adipocytes (31) stained with Hoechst and MayGrünwald/giemsa. Glycerol released to the medium increased proportionally with cell concentration, between $3 \times 10^{5}$ and $12 \times 10^{5}$ cells $/ \mathrm{ml}$ (Fig. $2 A$ ). A concentration of $6 \times 10^{5}$ cells/ml was selected to ensure that the subsequent studies would have suitable measurements.

Time course experiments from 1 to $7 \mathrm{~h}$ of incubation showed a linear increase in the level of lipolysis (Fig. 2B). A period of incubation of $6 \mathrm{~h}$ was selected because previous results showed that this time is optimal for assessing either the inhibitory or stimulatory action of hormones (data not shown).

Effects of diet and fasting on morphological parameters, plasma metabolites and insulin levels, and isolated adipocyte lipolysis. PP-fed fish had significantly lower liver mass than FM-fed fish. No significant differences were found in body mass, adipose tissue content, and hepatosomatic index between PP-fed and FM-fed fish (Table 2). Fasting for 11 days induced a decrease in body mass and a clear decrease in liver weight of $\sim 50 \%$, provoking a marked fall in the hepatosomatic index in both groups (Table 2).

Plasma insulin levels in fed seabream were similar between dietary groups and decreased with fasting only in the PP-fasted group (Fig. 3A). Glycemia levels were similar in all conditions, ranging from 5.03 to $6.53 \mathrm{mmol} / \mathrm{l}$. Plasma FFA levels increased significantly with fasting in both groups (Fig. $3 B$ ).

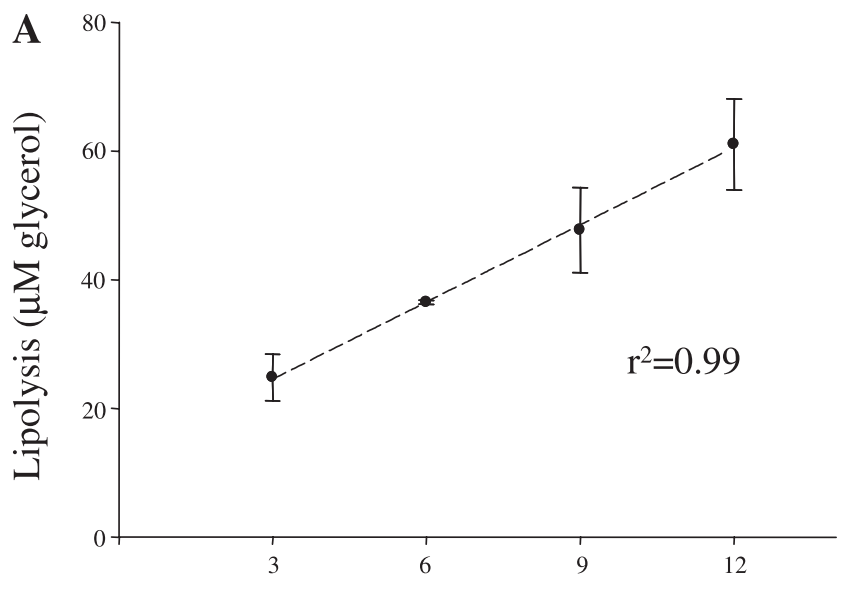

Cell concentration $\left(10^{5}\right.$ adipocytes $\left./ \mathrm{mL}\right)$

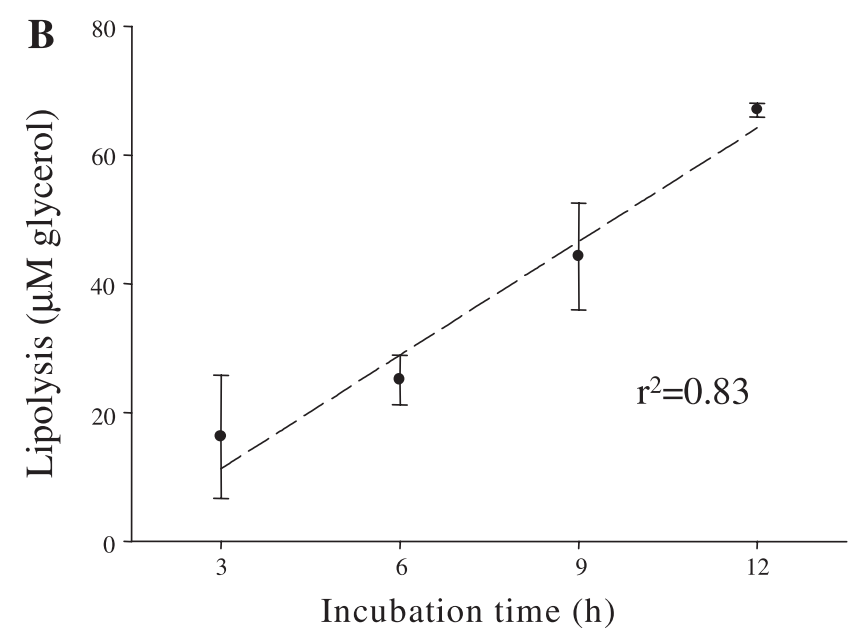

Fig. 2. Effect of increasing concentrations of adipocytes on basal lipolysis $(A)$ and time course of basal lipolysis of gilthead seabream adipocytes having up to $7 \mathrm{~h}$ of incubation time $(B)$. Values are means $\pm \mathrm{SE}$ of a representative experiment; $n=3$. Results were fitted to linear regression: $r^{2}=0.99(A)$ and $r^{2}=0.83(B)$.

The lipolytic rate, measured as glycerol released to the medium, was significantly higher in adipocytes from PP-fed fish (Fig. 4). Fasting provoked an almost threefold increase in the lipolytic rate in isolated adipocytes: from 5.71 to 16.25 nmol glycerol $\cdot \mathrm{h}^{-1} \cdot 10^{-6}$ cells in the FM group and from 8.58 to $21.47 \mathrm{nmol}$ glycerol $\cdot \mathrm{h}^{-1} \cdot 10^{-6}$ cells in the PP group (Fig. 4).

Effects of incubations with hormones in isolated adipocytes. The effects of hormones on lipolysis of adipocytes from the FM-fed group are shown in Fig. 5A and after the fasting period in Fig. 5B. In the FM-fed group, insulin did not induce any significant change in lipolysis. Glucagon led to a significant increase in lipolysis in fed fish at the higher dose (100 nM). GH was clearly lipolytic (increases of between 192 and 249\% over control) in FM-fed animals, although no clear dose response was observed. The relative response to $\mathrm{GH}$ was lower in cells from fasted fish, in which increases varied from 135 to $176 \%$ over control.

The effects of hormones on the lipolysis of adipocytes from PP-fed and PP-fasted fish are shown in Fig. 6, $A$ and $B$, respectively. Insulin $(10 \mathrm{nM})$ decreased lipolysis in PP-fed fish, 
Table 2. Morphological parameters of gilthead seabream used in the experiments

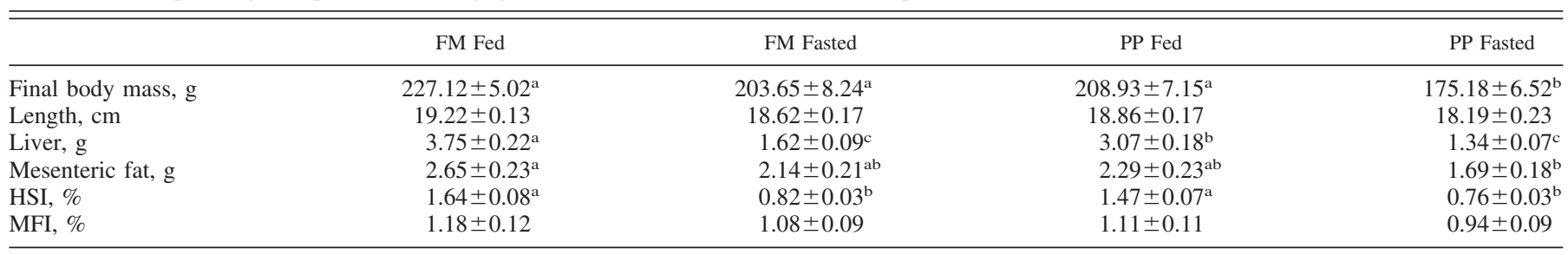

Values are average \pm SE; $n=17$ FM-fed and 17-FM-Fasted fish and $n=15$ PP-fed and 15 PP-fasted fish. Results were analyzed by one-way ANOVA, followed by Tukey's test. HSI, hepatosomatic index [(liver wt/fish wt $) \times 100]$; MFI, mesenteric fat index [(mesenteric fat wt/fish wt $) \times 100]$. Data for HSI and MFI were arc-sine transformed before statistical analysis was done. Values not sharing a common letter are significantly different $(P<0.05)$.

whereas this hormone had no effect in PP-fasted fish. The lipolytic effect of glucagon was significant after incubations with $10 \mathrm{nM}$ glucagon in both fed and fasted fish. GH stimulated lipolysis in the PP-fed group at two of the three concentrations tested, whereas in the PP-fasted group only a significantly higher lipolysis was observed after incubation with the $1 \mathrm{nM}$ hormone concentration.

\section{DISCUSSION}

Ectotherms, which have relatively low basal metabolic rates, store substantial amounts of lipid in their livers but also do so
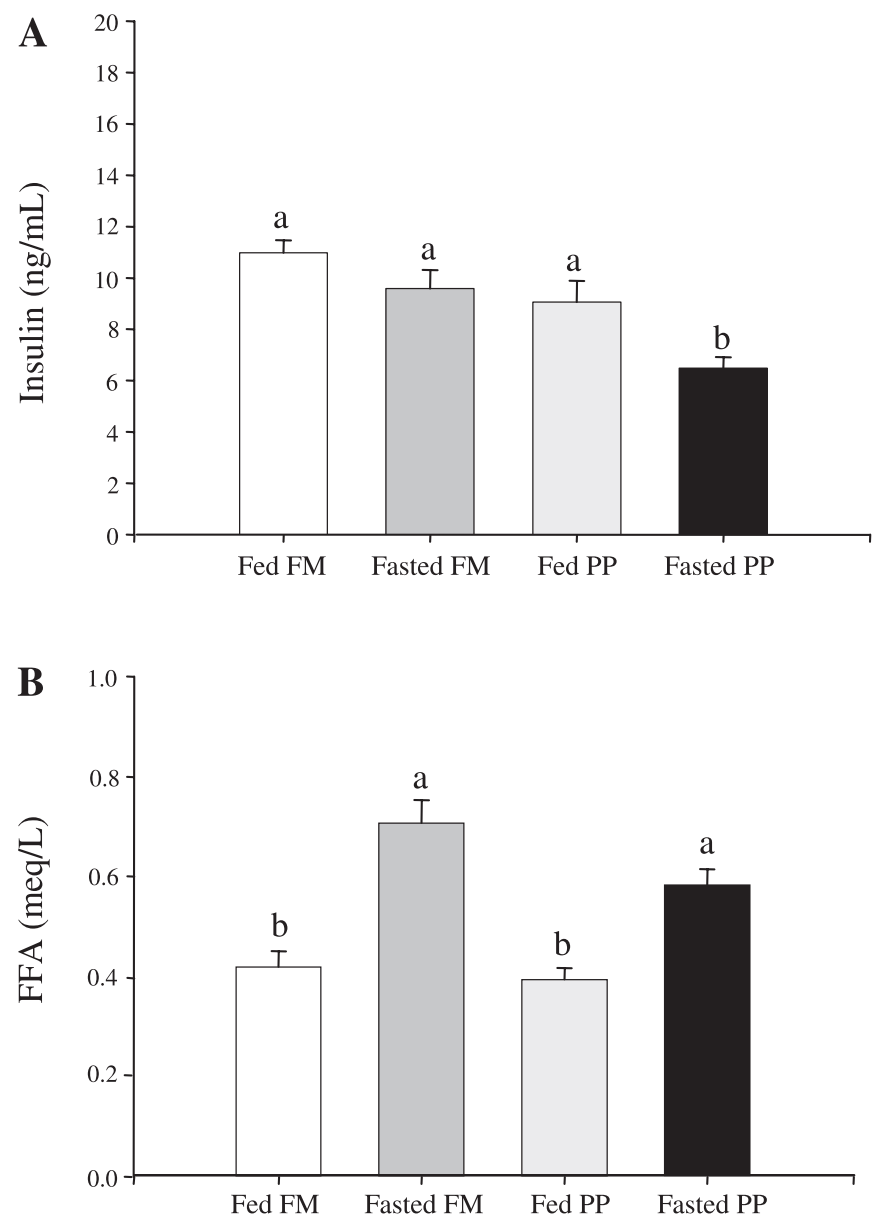

Fig. 3. Plasma levels of insulin $(A)$ and free fatty acids (FFA; $B$ ) in gilthead seabream fed (after overnight fasting) and fasted (for 11 days) from fishmeal (FM) and plant protein (PP) groups. See text for further details of groups. Values are means $\pm \mathrm{SE} ; n=17 \mathrm{FM}$-fed and $n=17 \mathrm{FM}$-fasted fish and $n=$ 15 PP-fed and $n=15$ PP-fasted fish. Statistical analysis was done as in Table 2. Values not sharing a common letter are significantly different $(P<0.05)$. in the mesenteric adipose tissue, which has gained metabolic importance through vertebrate evolution. Adipose tissue is distributed in the abdominal cavity located periviscerally in many fish species, including gilthead seabream. Few studies have analyzed the morphology and distribution of adipose cells in visceral fat and muscle of salmonids $(9,42)$. Although there is abundant literature on the endocrine control of adipocyte function in either isolated or cultured mammalian adipose cells $(16,40)$, this in vitro model has not been fully studied in fish $(23,38,41)$

Our findings that the rate of lipolysis was proportional to cell density and linear with incubation time, as observed in mammals (37), together with microscopic characteristics and the specific stain, confirm that gilthead seabream-isolated adipocytes are suitable for the study of the regulation of lipolysis by different effectors. Considering the time of incubation, the lipolytic rate calculated in gilthead seabream-isolated adipocytes $\left(5.71 \mathrm{nmol} \cdot \mathrm{h}^{-1} \cdot 10^{-6}\right.$ cells) was lower than those previously reported in rainbow trout adipocytes in similar experimental conditions $\left(8.9-12.8 \mathrm{nmol} \cdot \mathrm{h}^{-1} \cdot 10^{-6}\right.$ cells) working at different temperatures of incubation (rainbow trout adipocytes at $15^{\circ} \mathrm{C}$ and seabream adipocytes at $22^{\circ} \mathrm{C}$ ) (1). The lipolytic activity in the fish species studied until now is lower than in mammals [reviewed by Van den Thillart et al. (38)]. However, the differences in temperature of incubation in mammalian and piscine systems $\left(37^{\circ} \mathrm{C}\right.$ vs. $\left.15-22^{\circ} \mathrm{C}\right)$ have to be taken into account.

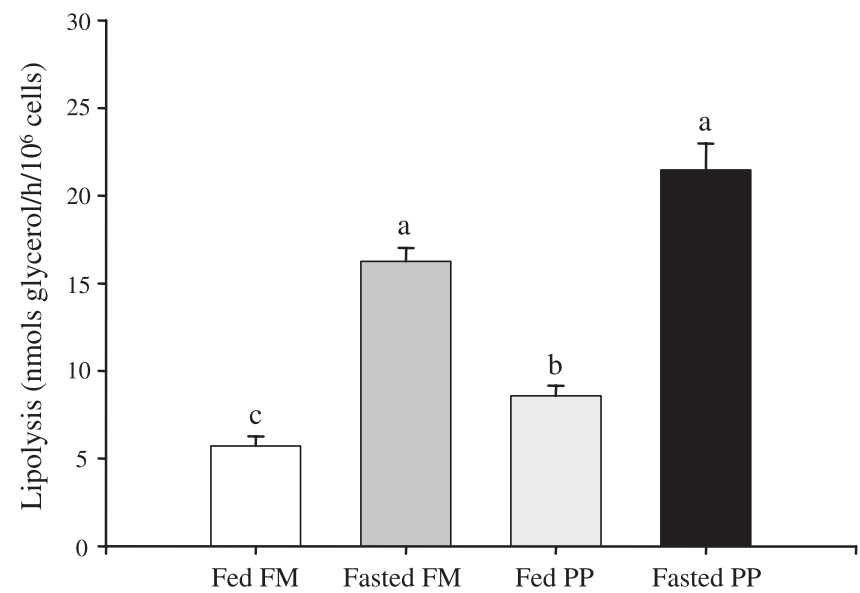

Fig. 4. Basal lipolysis after $6 \mathrm{~h}$ of incubation of adipocytes from fed and fasted gilthead seabream FM and PP groups. Values are the average of tetraplicates from 3 independent experiments \pm SE. Results were analyzed by one-way ANOVA, followed by the Games-Howell test. Values not sharing a common letter are significantly different $(P<0.05)$. 
A growth trial of 12 wk previously performed during AprilJuly in gilthead seabream adapted to the same diet under similar experimental conditions resulted in a reduction in growth rate from $1.86 \%$ (FM group) to $1.56 \%$ (PP group) (10). Although the factors responsible for altered feeding behavior in fish fed substituted diets are not clear (antinutritional factors, low palatability, and amino acid composition), it appears that the effect is more pronounced over time. Thus the shorter period of adaptation to diet ( $6 \mathrm{wk})$ in the present study may explain the lower impact of diet on growth rate. The levels of lipolysis in adipocytes from the PP-fed fish were higher than in
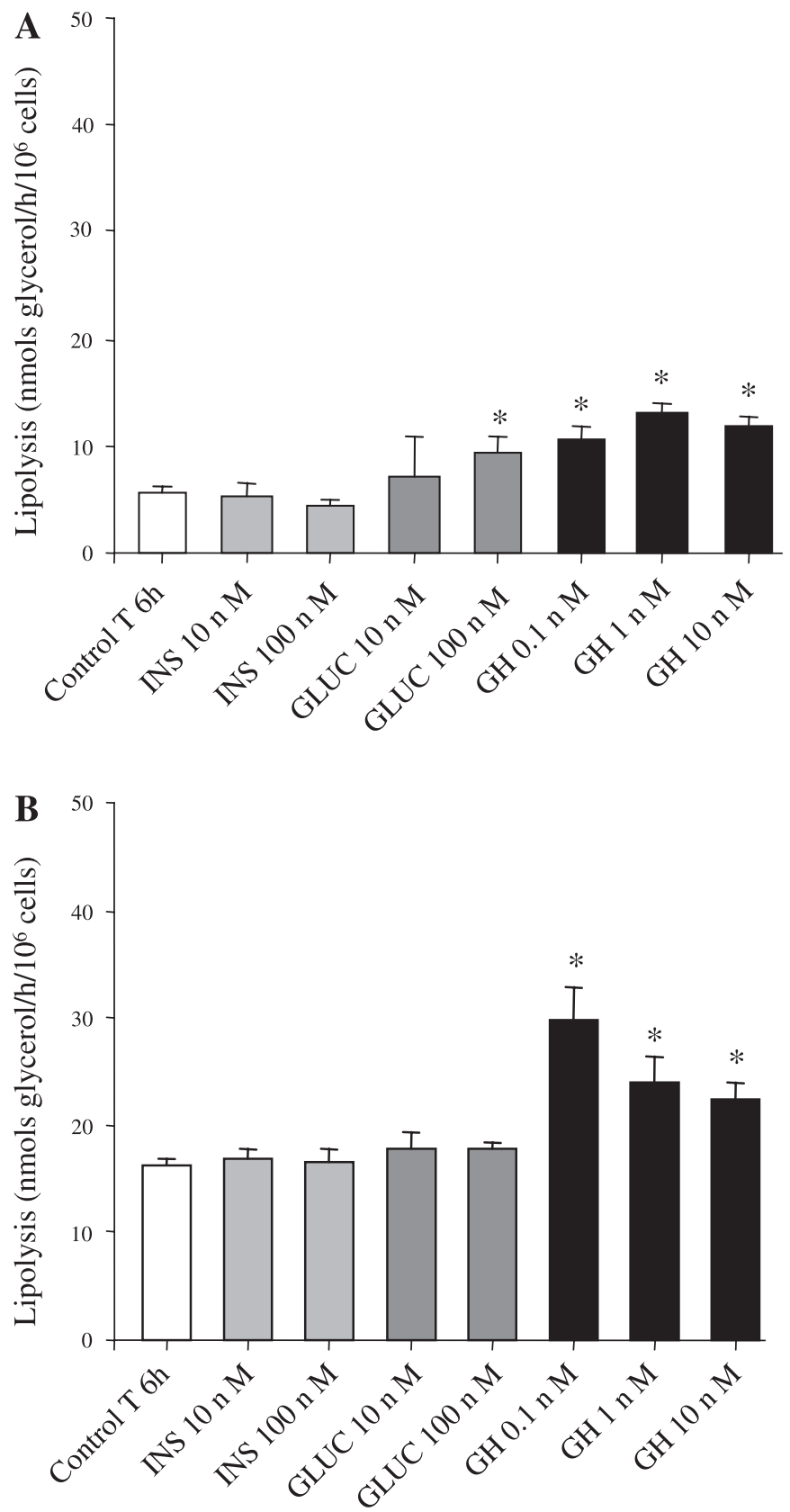

Fig. 5. Hormone effect on adipocyte lipolysis of FM-fed (A) and FM-fasted $(B)$ fish. Values are means $\pm \mathrm{SE}$ of triplicates from 3 independent experiments. INS, insulin; GLUC, glucagon; GH, growth hormone; T, time. Results were statistically analyzed by paired $t$-test. *Significant differences between control and each of the hormones tested $(P<0.05)$.
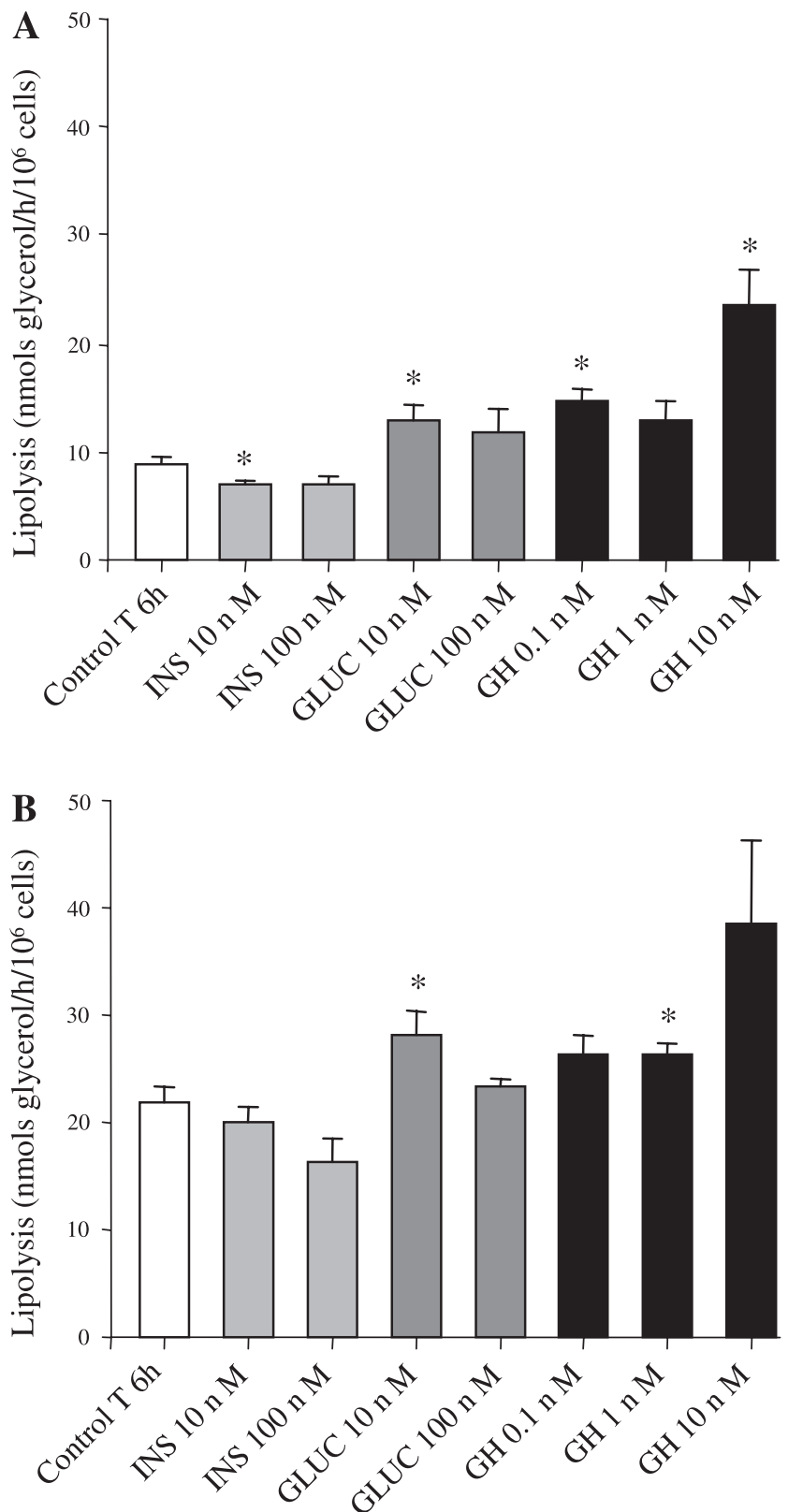

Fig. 6. Hormone effect on adipocyte lipolysis of PP-fed $(A)$ and PP-fasted $(B)$ fish. Values are means $\pm \mathrm{SE}$ of triplicates from 3 independent experiments $(n=9)$. Results were statistically analyzed as in Fig. 5. *Significant differences between control and each of the hormones tested.

the FM-fed fish. These results are in agreement with earlier observations regarding lipid metabolism in seabream (10) and other teleostean species fed with diets with high plant protein content $(6,17)$ : a decrease in lipid deposition and mesenteric fat together with a clear hypocholesterolemia and a decrease in postprandial plasma triglyceride levels. Because changes in the rate of adipocyte lipolysis were weak, these changes were not reflected in the levels of plasma FFA, which remained similar in both groups in the fed condition.

The decrease in weight and relative liver size after fasting corroborates the finding that food deprivation significantly affects the metabolic status of seabream (24). Our data also show that previous nutritional history has a significant effect on 
catabolism induced by fasting because fish from the PP group responded differently from the FM-fed group. Seabream in the PP group were the most affected by fasting, presenting the lowest body weight, liver weight, and plasma insulin levels. Plasma FFA increased in both fasted groups, whereas glucose was maintained. An increase in plasma FFA together with normoglycemia has been also reported in fasted salmon (Oncorhynchus kisutch). This increase was found to be related to lipid depot mobilization and increases in gluconeogenesis (32). Furthermore, and in agreement with the increase in plasma FFA irrespective of the previous diet, there was a clear increase in lipolytic activity in seabream adipocytes from fasted fish, indicating a significant contribution of adipose tissue to lipid mobilization. Nevertheless, other tissues such as liver and muscle may play an important role in the observed increase of plasma FFA. To our knowledge, this is the first demonstration that lipolysis measured in isolated adipocytes is affected by the nutritional status of fish. This effect has been reported in mammalian species, such as rats, in which a short fasting period induced an increase of plasma FFA concomitant with increases in basal lipolysis levels in isolated adipocytes from adipose tissue (22). This breakdown of triglycerides and the decrease in abdominal fat tissue weight indicate a relatively rapid mobilization (after 11-13 days of fasting) of lipid depots to meet energy demands in seabream compared with other species (24). The previous adaptation does not seem to affect the lipid mobilization capacity during fasting, since the increase in glycerol release in fasted fish in relation to fed fish was similar in both groups. Nevertheless, the maximum levels of lipolysis were observed in fasted PP with the minimum values of plasma insulin, which suggested a possible role of this hormone in the regulation of lipolysis in adipocytes.

Under our conditions, insulin did not affect notably the rate of lipolysis in vitro. Insulin is involved in the stimulation of glucose carbon conversion into lipid in hepatocytes (30) of rainbow trout. Antilipolytic actions of insulin have been reported in incubations of salmon liver and adipose tissue pieces (12). Besides, specific insulin receptors have also been characterized in trout adipose tissue (27). In fact, mammalian insulin has been shown to stimulate glucose uptake in isolated trout adipocytes (3). A possible explanation of the observed low or absence of response of adipocyte lipolysis to insulin could be related to the effects described in mammals by Morimoto et al. (22), who reported that insulin preferentially decreased the lipolytic rate of adipocytes previously increased by other hormones such as catecholamines, rather than affecting the basal lipolytic activity in isolated rat adipocytes. In the same way, in hepatocytes from fed rainbow trout, insulin depressed glucagon-stimulated lipolysis, whereas basal lipolysis was not affected (13).

Both glucagon and GH are lipolytic in seabream cell incubations, with $\mathrm{GH}$ being more potent in activating glycerol release to the medium. Nevertheless, the fact that the GH used was homologous to the species studied has to be taken into account. The relative increase in lipolysis after GH incubations in fasted fish was lower than in fed fish, which could be a consequence of the already higher rate of lipolysis in fasted fish. From our data, we cannot deduce a change in hormone sensitivity, although in other fish models, such as hepatocytes, fasting affected the responsiveness to hormone stimulation $(13,26)$.
Early studies performed in fish adipose tissue slices or adipocytes showed an absence or a very low response of this tissue to hormones such as catecholamines, glucagon, and $\operatorname{ACTH}(8,23)$. Only recently an inhibition of lipolytic rate after catecholamine incubation has been observed in isolated adipocytes from tilapia, which has been associated with resistance to hypoxia (41). The observed effects of glucagon in our study agree with the lipolytic action through stimulation of liver triacylglycerol lipase in fish (33). Besides, glucagon stimulated lipid breakdown in liver and adipose tissue pieces from rainbow trout (12). It appears then that glucagon is able to mobilize triglyceride depots not only from liver but also from adipose tissue, as in mammals, although glucagon has a stronger lipolytic potency in mammalian systems $(25,36)$.

Lipolytic actions of $\mathrm{GH}$ are in agreement with the antilipogenic effects previously found for this hormone, such as inhibition of acetyl-CoA carboxylase in the liver of gilthead seabream (39). Its lipolytic function correlates well with the increases in GH plasma levels in experimentally fasted seabream (5) or trout (2).

In summary, lipolysis of adipocytes isolated from adipose tissue of seabream is clearly modulated by the nutritional condition of the fish. These cells increase the lipolytic activity in the presence of glucagon and GH. However, further studies are needed to understand fully the endocrine regulation of adipose tissue metabolism in fish.

\section{GRANTS}

This study was funded by the European Union (Q5RS-2000-30068) "Perspectives of Plant Protein Use in Aquaculture" and by the Centre de Referència de Recerca i Desenvolupament en Aqüicultura de la Generalitat de Catalunya (CRA-2003-2.2/ 333038).

\section{REFERENCES}

1. Albalat A, Vianen G, Gutiérrez J, Planas JV, van den Thillart G, and Navarro I. Hormonal regulation of rainbow trout adipocyte lipolysis. In: 21st Conference of European Comparative Endocrinologists. Bonn, Germany: University of Bonn, 2002.

2. Barrett BA and McKeown BA. Sustained exercise augments long-term starvation increases in plasma growth hormone in the steelhead trout, Salmo gairdneri. Can J Zool 66: 853-855, 1988.

3. Capilla E, Diaz M, Albalat A, Navarro I, Pessin JE, Keller K, and Planas JV. Functional characterization of an insulin-responsive glucose transporter (GLUT4) from fish adipose tissue. Am J Physiol Endocrinol Metab 287: E348-E357, 2004.

4. Company R, Calduch-Giner J, Kaushik S, and Pérez-Sánchez J. Growth performance and adiposity in gilthead seabream (Sparus aurata): risks and benefits of the high energy diets. Aquaculture 171: 279-292, 1999

5. Company R, Astola A, Pendón C, Valdivia MM, and Pérez-Sanchez J. Somatotropic regulation of fish growth and adiposity: growth hormone (GH) and somatolactin (SL) relationship. Comp Biochem Physiol C 130: 435-445, 2001.

6. Dias J. Lipid Deposition in Rainbow Trout (Oncorhynchus mykiss) and European Sea Bass (Dicentrarchus labrax): Nutritional Control of Hepatic Lipogenesis ( $\mathrm{PhD}$ thesis). Porto, Portugal: University of Porto and University of Bordeaux, 1999.

7. Einen $\mathbf{O}$ and Skrede GG. Quality characteristics in raw and smoked fillets of Atlantic salmon, Salmo salar, fed high-energy diets. Aquacul Nutr 4: 99-108, 1998.

8. Farkas T. Studies on the mobilization of fats in lower vertebrates. Acta Biochim Biophys Acad Sci Hung 4: 237-249, 1969.

9. Fauconneau B, Andree S, Chmaitilly J, Le Bail PY, Krieg F, and Kaushik SJ. Control of skeletal muscle fibres and adipose cells size in the flesh of rainbow trout. J Fish Biol 50: 296-314, 1997.

10. Gómez-Requeni P, Mingarro M, Calduch-Giner JA, Médale F, Martin SAM, Houlihan DF, Kaushik S, and Pérez-Sanchez J. Protein 
growth performance, amino acid ulilisation and somatotropic axis responsiveness to fish meal replacement by plan protein sources in gilthead seabream (Sparus aurata). Aquaculture 232: 493-510, 2004.

11. Gutiérrez J, Carrillo M, Zanuy S, and Planas J. Daily rhythms of insulin and glucose levels in the plasma of sea bass Dicentrarchus labrax after experimental feeding. Gen Comp Endocrinol 55: 393-397, 1984.

12. Harmon JS and Sheridan MA. Effects of nutritional state, insulin, and glucagon on lipid mobilization in rainbow trout, Oncorhynchus mykiss. Gen Comp Endocrinol 87: 214-221, 1992.

13. Harmon JS and Sheridan MA. Previous nutritional state and glucose modulate glucagon-mediated hepatic lipolysis in rainbow trout, Oncorhynchus mykiss. Zool Sci 9: 275-281, 1992.

14. Harmon JS, Rieniets LS, and Sheridan MA. Glucagon and insulin regulate lipolysis in trout liver by altering phosphorylation of triacylglycerol lipase. Am J Physiol Regul Integr Comp Physiol 265: R255-R260, 1993.

15. Huggett AS and Nixon DA. Use of glucose oxidase, peroxidase, and $O$-dianisidine in determination of blood and urinary glucose. Lancet 24 : 368-370, 1957.

16. Jensen DJ. Lipolysis: contribution from regional fat. Annu Rev Nutr 17: 127-139, 1997.

17. Kaushik SJ, Cravedi JP, Lalles JP, Sumpter J, Fauconneau B, and Laroche M. Partial or total replacement of fish meal by soybean protein on growth, protein utilization, potential estrogenic or antigenic effects, cholesterolemia and flesh quality in rainbow trout, Oncorhynchus mykiss. Aquaculture 133: 257-274, 1995

18. Martínez-Barbera JP, Pendón C, Martí-Palanca H, Calduch-Giner JA, Rodríguez R, Valdivia MM, and Pérez-Sánchez J. The use of recombinant gilthead seabream growth hormone for radioiodation and standard preparation in radioimmunoassay. Comp Biochem Physiol 110A: 335-340, 1995.

19. Migliorini RH, Lima-Verde JS, Machado CR, Cardona GMP, Garofalo MAR, and Kettelhut IC. Control of adipose tissue lipolysis in ectotherm vertebrates. Am J Physiol Regul Integr Comp Physiol 263: R857-R862, 1992.

20. Mingarro M, Vega-Rubín de Celis S, Astola A, Pendon C, Valdivia MM, and Pérez-Sánchez J. Endocrine mediators of seasonal growth in gilthead seabream (Sparus aurata): the growth hormone and somatolactin paradigm. Gen Comp Endocrinol 128: 102-111, 2002.

21. Mommsen TP and Plisetskaya EM. Insulin in fishes and agnathans: history, structure and metabolic regulation. Rev Aquat Sci 4: 225-259, 1991.

22. Morimoto C, Takahiro T, and Okuda H. Antilipolytic actions of insulin on basal and hormone-induced lipolysis in rat adipocytes. J Lipid Res 39: 957-962, 1998.

23. Murat JC, Carpene C, Woo NYS, Berlan M, Lafontan M, and Fraisse I. Comparative study on isolated adipocytes: Specific differences in the responsiveness to hormones. In: Current Trends in Comparative Endocrinology, edited by Lofts B and Holmes WN. Hong Kong: Hong Kong Univ. Press, 1985

24. Navarro I and Gutiérrez J. Fasting and starvation. In: Biochemistry and Molecular Biology of Fishes, edited by Hochachka PW and Mommsen TP. Amsterdam: Elsevier, 1995, vol. 4, p. 393-434.

25. Perea A, Clemente F, Martinell J, Villanueva-Penacarrillo ML, and Valverde I. Physiological Effect of glucagon in human isolated adipocytes. Horm Metab Res 27: 372-375, 1995.
26. Pereira C, Vijayan MM, and Moon TW. In vitro hepatocyte metabolism of alanine and glucose and the response to insulin in fed and fasted rainbow trout. J Exp Zool 271: 425-431, 1995.

27. Planas J, Mendez E, Baños N, Capilla E, Navarro I, and Gutiérrez J. Insulin and IGF-I receptors in trout adipose tissue are physiologically regulated by circulating hormone levels. J Exp Biol 203: 1153-1159, 2000 .

28. Plisetskaya EM. Fatty acid levels in blood of cyclostomes and fish Environ Biol Fish 5: 273-290, 1980.

29. Sala-Rabanal M, Sánchez J, Ibarz A, Fernández-Borràs J, Blasco J, and Gallardo MA. Effects of low temperatures and fasting on hematology and plasma composition of gilthead seabream (Sparus aurata). Fish Physiol Biochem 29: 105-115, 2003.

30. Segner H, Blair JB, Wirtz G, and Miller MR. Cultured trout liver cells: utilization of substrates and response to hormones. In Vitro Cell Dev Biol Anim 30A: 306-311, 1994.

31. Sheridan MA and Harmon JS. Biochemistry and Molecular Biology of Fishes, edited by Hochachka PW and Mommsen TP. Amsterdam, Elsevier, 1994, vol. 3, p. 305-311.

32. Sheridan MA and Mommsen T. Effects of nutritional state on in vivo lipid and carbohydrate metabolism of coho salmon, Oncorhynchus kisutch. Gen Comp Endocrinol 81: 473-483, 1991.

33. Sheridan MA. Lipid dynamics in fish: aspects of absorption, transportation, deposition and mobilization. Comp Biochem Physiol B 90: 679-690, 1988.

34. Steinberg D. Fatty acid mobilization-mechanisms of regulation and metabolic consequences. Biochem Soc Symp 24: 111-143, 1963.

35. Tebar F, Grau M, Mena MP, Arnau A, Soley M, and Ramírez I. Epidermal growth factor secreted from submandibular salivary glands interferes with the lipolytic effect of adrenaline in mice. Endocrinology 141: 876-882, 2002.

36. Tebar F, Soley M, and Ramírez I. The antilipolytic effects of insulin and epidermal growth factor in rat adipocytes are mediated by different mechanisms. Endocrinology 137: 4181-4188, 1996.

37. Tebar F, Ramírez I, and Soley M. Epidermal growth factor modulates the lipolytic action of catecholamines in rat adipocytes. J Biol Chem 268: 17199-17204, 1993.

38. Van den Thillart G, Vianen G, and Zaagsma J. Adrenergic regulation of lipid mobilization in fishes; a possible role in hypoxia survival. Fish Physiol Biochem 27: 189-204, 2002.

39. Vega-Rubín de Celis S, Gómez P, Calduch-Giner JA, Médale F, and Pérez-Sánchez J. Expression and characterisation of European sea bass (Dicentrarchus labrax) somatolactin (SL): assessment of in vivo metabolic effects. Mar Biotechnol (NY) 5: 92-101, 2003.

40. Vernon RG. Adipocyte studies: systems for investigating effects of growth hormone and other chronically acting hormones. Biochem Soc Trans 28: 126-131, 2000 .

41. Vianen GJ, Obels PP, van den Thillart G, and Zaagsma J. $\beta$-Adrenoceptors mediate inhibition of lipolysis in adipocytes of tilapia (Oreochromis mossambicus). Am J Physiol Endocrinol Metab 282: E318-E325, 2002 .

42. Zhou S, Ackman RG, and Morrison C. Adipocytes and lipid distribution in the muscle tissue of Atlantic salmon (Salmo salar). Can J Fish Aquat Sci 53: 326-332, 1996. 